\title{
Adult Brain: Game of Metaphors for Understanding the Internet
}

\author{
LORENA BORT-Mir \\ GReSCA Research Group, Departament Estudis Anglesos. Universitat Jaume I, Castellón, Spain \\ al091788@uji.es
}

\begin{abstract}
With the increasing apogee of the digital world and Internet use by older people, one may wonder how adults understand these virtual spaces. The aim of this article is to see to what extent the Conceptual Theory of Metaphor and the Idealized Cognitive Models (Lakoff and Johnson, 1980) may help understand the meaning and structure of a website.

In our research we analyze several web pages from the point of view of Cognitive Linguistics in order to know if the virtual world makes sense from different types of metaphors and cognitive domains. As linguists, we get two questions. The first one is whether we are able to understand the Internet, something abstract with which we are not born, and the way we surf websites, transferring meaning through conceptual metaphors from the real world we do know to this new online world. Throughout our analysis we can see what types of metaphors are activated in our mind when visiting a website and in which moment they transfer meaning from the real world.

The second question is whether website domains (the addresses of web spaces) are conceptually comparable to the cognitive domains that are activated in our minds when we perceive any concept. This assumption can offer a great contribution to marketers and SEO experts since it offers a new vision on how to make a potential client think what companies want (what mental model must be activated) when reading the address of a website.

In short, our brief analysis, which is part of a more thorough and extensive research, provides a theory on how online readers configure the meaning of websites through conceptual metaphors, and it also provides a new framework of study which examines how web domains should be established so that the reader is able to know the theme of the web with just reading its address.
\end{abstract}

Keywords: Metaphor, Idealized Cognitive Models, digital literacy, Conceptual Theory of Metaphor, Mental-Model Activators, Mental Hypothesis of Website Domains.

\section{Resumen}

Con el creciente apogeo del mundo digital y el uso de internet por la gente mayor, uno se pregunta cómo comprendemos los adultos estos espacios virtuales. El objetivo de este artículo es ver en qué medida la Teoría de la Metáfora Conceptual y los Modelos Cognitivos Idealizados (Lakoff and Johnson, 1980) pueden ayudar a entender el significado y estructura de una web.

En nuestra investigación analizamos varias páginas web desde el punto de vista de la Lingüística Cognitiva para saber si el mundo virtual toma sentido con metáforas y dominios cognitivos. Como lingüistas nos hacemos dos preguntas. La primera es si somos capaces de comprender internet, algo abstracto, y el modo en que navegamos por la red, transfiriendo significado del mundo real al mundo online a través de metáforas conceptuales. La segunda pregunta es si los dominios web (las direcciones de las páginas web) son conceptualmente comparables con los dominios cognitivos que se activan en nuestras mentes al percibir cualquier concepto.

En resumen, nuestro breve análisis, que es parte de una investigación más extensa, aporta una teoría sobre cómo los lectores digitales configuran el significado de las páginas web a través de metáforas conceptuales, y también aporta un nuevo marco de estudio que examina cómo los dominios web deberían estar configurados para que el lector sepa cuál va a ser la temática de esa web.

Palabras clave: Teoría de la Metáfora Conceptual, lectura digital, Modelos Cognitivos Idealizados. 


\section{Theoretical Framework}

With the growing usage of the Internet, much research has appeared about the knowledge and skills that the general public needs to engage with the media (Eshet, 2004; Lankshear and Knobel, 2008). These competencies encompass what is called digital literacy (Gilster, 1997). From a Cognitive Linguistic approach, the question we pose in this paper is: how do adults understand websites and configure their meaning and usage?

Children and young people approach the Internet in a natural way because they are born with the online world in their lives; adults, on the contrary, approach the Internet as a medium to perform an action such as sending an email or looking for certain information. Internet didn't exist when our generation was born, and the way we understand these online situations may constitute an interesting point of research. Thus, researchers such as Toms \& Campbell (1999: 3) have remarked that our digital literacy has provoked research on how users interact with online genres. Others suggest that the patterns that users follow when navigating through the Internet could be directed by previous knowledge about spatial models such as site, house or journey (Navarro 2008; Navarro et al. 2008; Navarro, Aguado and Silvestre, 2008; Navarro \& Silvestre 2009).

The aim of this paper is to spread some evidence on the metaphorical models that may help users understand the way websites and its addresses are structured, and identify and comprehend concepts that do not exist in the real world.

\section{How do we understand websites?}

Girón-García and Navarro (2014: 162) state that digital reading may be seen as a cognitive process through which users establish relationships between what they perceive in the screen and their previous knowledge configurations in order to associate meaning to a digital environment.
Readers may transfer their previous knowledge of other genres and their social and individual experience when approaching a website. This means that they are understanding one idea (e.g. a blog) in terms of another (e.g. a real newspaper), that is, readers may understand the virtual world through conceptual metaphors from the real world. This idea was first introduced by Lakoff and Johnson (1980: 5 ). They pointed out that «the essence of metaphor is understanding and experiencing one kind of thing in terms of another». For instance, we are understanding TIME in terms of MONEY, and so we have the conceptual metaphor TIME IS MONEY (e.g. You are wasting my time, this app will save you hours, etc.). In this example, we use a metaphor as a mapping from MONEY (source domain) to TIME (target domain); we use the concept of money (specific) to talk about the concept of time (abstract).

Thus, if we take the example of the metaphor READING A WEBSITE is VISITING A LOCATION, the Idealized Cognitive Model (henceforth ICM) (Lakoff, 1987) for our understanding of visiting a location offers us the information, concepts and relations we need in order to configure our knowledge about how to read a website (Girón-García and Navarro, 2014).

\subsection{Question one: a cognitive linguistic approach to metaphors}

In this paper we try to see how metaphorical models may «provide a conceptual guide for users to construct meaning through their trajectories across hypertexts» and websites (Girón-García and Navarro, 2014: 167). This means that when readers activate, mainly unconsciously, a certain metaphorical model, it gives them expectations about the text (the website), how to look at it and how to manage that information. We could even state that it is the reader, with the activation of those mental models, who constructs meaning, and thus the website (the set of texts, icons, images, page frames, etc.) is coherent and makes sense. (Navarro and Silvestre, 2009).

\footnotetext{
* Financiación proporcionada por «Pla 2014 de foment de la investigació de la UJI», referencia del proyecto: p1.1A2014-02.
} 


\subsection{Question two: a cognitive linguistic approach to website addresses}

Taking into account the above mentioned ICMs, the same setting of the virtual world, which may configure its meaning through metaphors, could be transferred to the concept of web addresses (domains).

Every site on the Internet has a name, an address, called domain; our proposal in this paper is that these domains could be identified in terms of cognitive domains since they activate a whole mental model. This concept may be better understood with the following graph.

We perceive a concept (by reading or hearing it, e.g. «radio»), and if we know that concept, our knowledge about it helps in the comprehension of the concept, and then a mental model is activated. The same happens with website domains. When we read a website address, if that address contains keywords or metaphors from which we can deduce a meaning, our knowledge about those keywords or metaphors helps us understand what that website is about. On the contrary, when we read a website address which contains no keywords or metaphors that connect that address with the content of the website, then the reader does not activate any ICM, and thus cannot be able to know what the website is about until the reader visits the site and reads its content.

This new view could be an essential point for brand marketers because it would help companies to select the appropriate domain (address) for their websites, and thus lead to more clicks. What we state here could also be a cognitive linguistic explanation to the fact that Google better ranks those websites whose domains contain words that specify the content of the website (that is, keywords about the content of the website). Our analysis is presented here as a Mental Hypothesis of Website Domains.

\section{Methodology}

For the analysis of question one, we select different types of websites according to the different genres they represent and the several ICMs they activate in the reader's mind:

www.wikipedia.com and www.facebook.com

Then we look for the most recurrent metaphorical linguistic expressions in order to analyze which conceptual metaphors they refer to, because according to Kövecses (1993), the existence of a conceptual metaphor is revealed by the occurrence of metaphorical linguistic expressions. Finally, we analyze the configuration of those cognitive models.

For the analysis of question two, as we come from the field of Linguistics, we search on the Internet the arbitrary term «learning languages». With the results obtained from that search, we chose the ones that better explain our Mental Hypothesis of Website Domains.

\section{Analysis and results}

\subsection{Question one (Do we understand a web- site through conceptual metaphors?)}

Online readers interact quite a lot with websites: they make decisions as they click on icons, they

\begin{tabular}{|l|l|}
\hline $\begin{array}{l}\text { COGNITIVE DOMAIN } \\
\text { Perception (by seeing or hearing the } \\
\text { concept) }\end{array}$ & Perception (by reading the address) \\
\hline $\begin{array}{l}\text { Knowledge (experience and reasoning) } \\
\text { Comprehension (understanding concept) }\end{array}$ & Knowledge (experience and reasoning) \\
\hline MENTAL MODEL & MENTAL MODEL \\
\hline
\end{tabular}

Figure 1. Cognitive domains vs. website domains 
write opinions, share information, etc. According to the ICMs, they will understand this interaction with the screen by means of their previous knowledge or experience. Navarro \& Silvestre (2009) have illustrated five source domains that map onto the «website» domain: house, site, journey, book and net. Let us explain what these domains entail:

\section{The House Model}

According to this model, we approach a website as if we were entering or visiting a house, where some activities or events are going to happen. When we enter the house we may give a password or sign in and then we get logged in. There may be a house master who welcomes visitors and invites us to come in. Once we are in the house, we may walk through the different rooms (go back and forth through different pages and links), and within each room we may search for some objects or info we need. There can even be some rooms destined to particular purposes such as a chat room, or we can even write a post on a message board.

\section{The Site Model}

This model contains a site master who welcomes and invites visitors to go around. Visitors may sign in and remain logged, or they may move back and forth a path (links, menu).Visitors may need a sitemap to move through the site and even directions with you-are-here indications. Some sites contain shops or an info desk where visitors can approach and get answers (FAQs).

\section{The Journey Model}

This model takes into account a location where a journey begins and ends. The house indicates the point of departure to any destination. Visitors (surfers) may use menus for navigation.

\section{The Book Model}

The Book Model reminds visitors of the conceptualization of the reading process in traditional formats. Pages, table of contents, next page, and even bookmark may appear in these websites.

\section{The Net Model}

This model is activated by the expression link. Links may refer to buttons and marked expressions that lead to other screens.
For our present inductive research, we analyze just the main page of each site to make it simple and clear. We select certain linguistic expressions and even symbols that match the metaphorical models previously mentioned. The analysis of the selected websites proceeds as follows:

Wikipedia:

\begin{tabular}{|l|l|l|l|l|}
\hline $\begin{array}{l}\text { HOUSE } \\
\text { MODEL }\end{array}$ & SITE MODEL & $\begin{array}{l}\text { JOURNEY } \\
\text { MODEL }\end{array}$ & $\begin{array}{l}\text { BOOK } \\
\text { MODEL }\end{array}$ & NET MODEL \\
\hline Sign in & Sign in & Search & Main page & \\
\hline Logging & Logging & Explore & Contents & \\
\hline Welcome & Welcome & & Browse & \\
\hline Rooms & & & Index & \\
\hline & & & Print / Export & \\
\hline & & & Create a book & \\
\hline
\end{tabular}

Figure 2. Table of mental models

What this table reveals is that Wikipedia website shows certain aspects of four domains: house, site, journey and book, where book is the most remarkable one. We can see some examples of these domains in the following extract:

Welcome to Wikipedia, Create account, Log in, Search, All Portals (rooms), Main Page, Contents, Featured Contents, etc.

Thus, the Book Model maps into aspects related getting information, like finding or classifying that information, which is the aim of Wikipedia.

Facebook:

\begin{tabular}{|l|l|l|l|l|}
\hline $\begin{array}{l}\text { HOUSE } \\
\text { MODEL }\end{array}$ & SITE MODEL & $\begin{array}{l}\text { JOURNEY } \\
\text { MODEL }\end{array}$ & $\begin{array}{l}\text { BOOK } \\
\text { MODEL }\end{array}$ & NET MODEL \\
\hline Sign in & Sign in & & & Net \\
\hline Logging & Logging & & & Connect \\
\hline Invitation & & & & \\
\hline Password & & & & \\
\hline
\end{tabular}

Figure 3. Table of mental models

Facebook main page has little information but it is clearly a house model with a touch of the net model in the image that shows a world map with people connected by a net. The House Model makes visitors virtually interact with that house (that site) 
and with its inhabitants (other users or web masters), which is the aim of Facebook.

\subsection{Question two (Do we grasp the meaning of a website domain through ICMs?)}

For our analysis we search for the arbitrary term «learning languages» in an online browser and we find several interesting results:

\author{
www.learning-languages.com \\ www.babbel.com \\ https://www.duolingo.com \\ www.learnalanguage.com \\ www.livemocha.com \\ www.busuu.com
}

According to our Mental Hypothesis of Website Domains, we divide these website domains in two types, which we call Mental-Model Activators and Mental-Model Inhibitors. Mental-Model Activators are those websites whose addresses (their domain names) contain keywords which may help readers deduce what the website is about, that is, what they can expect from it. On the contrary, Mental-Model Inhibitors are those websites whose domain names (addresses) do not contain any keywords or metaphors which allow readers to infer their content. Let us see some examples:

\begin{tabular}{|l|l|}
\hline MENTAL-MODEL ACTIVATORS & MENTAL-MODEL INHIBITORS \\
\hline www.learning-languages.com & www.duolingo.com \\
\hline www.learnalanguage.com & www.livemocha.com \\
\hline www.babbel.com & www.busuu.com \\
\hline
\end{tabular}

Figure 4. Example of mental models

Mental-Model Activators:

- learning-languages.com: it activates the ICM of learning a language, because its domain contains words that specify the content of the website;

- learnalanguage.com: this website also activates the ICM of learning a language, because its domain contains words that specify the content of the website;

- babbel.com: this is an interesting website domain because even though it doesn't contain specific words that tell us what the website is about, we can infer its meaning through our knowledge of the word «babbel», which functions as a conceptual metaphor in this case.

Mental-Model Inhibitors:

- duolingo.com: this website domain could be classified into the two types of domains, and its classification depends on the knowledge the visitor has. According to the company, duolingo comes from «duo»+ «lingo», that is, «two languages». This can be inferred depending on the knowledge and skills of the visitor, so duolingo.com could be a Mental-Model Activator and a Mental-Model Inhibitor;

- livemocha.com: this website domain doesn't activate any mental model of the concept of learning languages. The name «Livemocha» is meant to evoke the relaxed atmosphere of a coffee shop, so it is up to the visitor to configure its meaning;

- busuu.com: the founders of this online website said that they wanted to do something about the extinction of the Busuu language, so they used that name for their company. This name, even though it activates the ICM of «languages» (just for those who know that that language exists), doesn't activate the specific ICM of «learning languages».

Our analysis leaves the door open to further research on the settings of website domains and how those names can lead visitors to click on one site or another, that is, choosing the proper website domain may lead to more visits and, consequently, to more online sales and increasing website analytics.

\section{Conclusions and further research}

The inferences that we can draw from our analysis can be well explained according to Navarro and Silvestre's ideas (2009: 288)

... each source ICM contributes to our understanding of websites as discursive organizations. Consequently, each model will prompt its own inferential patterns when the users give them preeminence in the process of reading a website. If the users prime the House Model, their first decisions might 
focus on reading the text on the home page in order to become familiar with the webmaster's background and purpose. Probably signing in to become a member would be one of the user's interest.

The results of the present study try to guess how metaphorical ICMs may guide the reader's usage and understanding of a website, and how the activation of ICMs can play a major role in the selection of website domains, since the design of a certain address may prompt readers to click on it or not.

Further research is needed in order to find out to what extent these mental structures based on conceptual metaphors (or metaphorical ICMs) are the same for the website developer and for its users.
Further research is also needed in order to know to what extent these cognitive models guide the users' navigation.

Our analysis of metaphorical virtual spaces and our emergent theory about the conceptual equity between cognitive domains and website domains could be a point to consider for marketers and SEO experts, since when a website structure and keywords match with the mental model they are supposed to activate, what we obtain is a very powerful website which could be, additionally, ranked in the first places by Google, which may be one of the most important objectives for companies in the present days.

\section{References}

Eshet, Y. (2004). Digital literacy: A conceptual framework for survival skills in the digital era. Journal of Educational Multimedia and Hypermedia, 13(1), 93-106.

Gilster, P., and Glister, P. (1997). Digital literacy. Wiley Computer Pub.

Girón-García, C., and Navarro, I. (2014). Digital Literacy and Metaphorical Models. Multidisciplinary Journal for Education, Social and Technological Sciences, 1(2), 160-180.

Kövecses, Z. (1993). Metaphor: A practical introduction. Oxford University Press.

Lakoff, G. J. (1985). M. (1980) Metaphors we live by. Chicago: The University of Chicago Press.

Lakoff, G. J. (1987). Women, Fire and Dangerous Things. What Categories Reveal about the Mind. The University of Chicago Press. DOI: 10.7208/chicago/9780226471013.001.0001

Lakoff, G. J., and Johnson, M. (1980). The metaphorical structure of the human conceptual system. Cognitive science, 4(2), 195-208.

Lankshear, C., and Knobel, M. (Eds.). (2008). Digital literacies: Concepts, policies and practices (Vol. 30). Peter Lang.

Navarro, I. (2008). Metaphorical ICMs in cybergenre representation, vol 7, Studia Universitatis Petru Maior. Series Philologia, Targu Mures. 167-177.

Navarro, I., Aguado, S., and Silvestre, A.J. (2008). Website Architecture, Information Flows and Cognitive Models. CORELL: Computer Resources for Language Learning 2, 46-63.

Navarro, I., and Silvestre, A. J. (2009). The Role of ICMs in Cybergenre Representation and Reading Modes. In M. Navarro Coy (ed.) Practical Approaches to Foreign Language Teaching and Learning. Linguistic Insights 78. Berlin/NY: Peter Lang. 269-292.ISBN: 978-3-03911-661-4.

Navarro, I., Villanueva, M.L., Girón-García, C., and Silvestre, A.J. (2008). Cybergenres and Autonomous Language Learning. Pragmatic Strategies and Cognitive Models in the Production and Processing of Digital Genres. INTED 2008 Proceedings. Organizado por IATED.

Ruiz de Mendoza Ibáñez, F. J., and Díez Velasco, O. I. (2003). Patterns of Conceptual Interaction. In Dirven, René \& Pörings, Ralph (eds) Metaphor and Metonymy in Comparison and Contrast. Berlin: Mouton de Gruyter, 489-532.

Toms, E.G., and Campbell, G. (1999). Genre as Interface Metaphor: Exploiting Form and Function in Digital Environments. Proceedings of the 32nd Hawaii International Conference on System Sciences. Maui, Hawaii IEEE Press, 2, 9pp. 